\title{
Effects of the Texas (USA) 'brown tide' alga on planktonic grazers
}

\author{
Edward J. Buskey*, Cammie J. Hyatt \\ Marine Science Institute, The University of Texas at Austin, Port Aransas, Texas 78373, USA
}

\begin{abstract}
The Laguna Madre of south Texas, USA, has experienced a dense, nearly monospecific phytoplankton bloom since January 1990 referred to as the 'brown tide'. Zooplankton populations declined following the outbreak of the bloom and planktonic grazers have failed to bring the bloom under control. Laboratory studies of microzooplankton grazers feeding on brown tide indicate that this alga is nutritionally inadequate to support the growth of several species including the ciliate Strombidinopsis sp., the heterotrophic dinoflagellate Noctiluca scintillans or the rotifer Brachionus plicatilus. The presence of brown tide also inhibits the growth of some species (Noctiluca scintillans, Brachionus plicatilus) even when other nutritionally adequate food species are present. Some species that grow on brown tide grow best at low cell concentrations, including the ciliates Fabrea salina and Euplotes sp:; as algal densities increase, growth rates decrease. Laboratory studies of egg release of adult female Acartia tonsa indicate that the brown tide is a poor food for these copepods; egg release rates are similar to those of starved copepods and less than those of copepods fed other similarly sized phytoplankton. The brown tide is toxic to early naupliar stages of Acartia tonsa but not to adults. The brown tide alga appears to be toxic to some species of planktonic grazers and a poor food for others; the reduced grazing by the planktonic community may be a contributing factor to the persistence of this bloom.
\end{abstract}

KEY WORDS: Harmful algal blooms $\cdot$ Zooplankton $\cdot$ Brown tides

\section{INTRODUCTION}

A dense algal bloom referred to as the 'brown tide' has affected regions of the south Texas (USA) coast centered around the Laguna Madre since January 1990. This persistent algal bloom has reduced the penetration of sunlight, shading out seagrass beds and disrupting sport fishing activities. Having now persisted for over $5 \mathrm{yr}$, this is one of the longest phytoplankton blooms that has been scientifically documented. The probable causes contributing to the initiation of this bloom have been well documented; both a period of extended drought, causing abnormally high salinities, and a severe freeze in December 1989 caused an abrupt decline in the populations of both planktonic and benthic phytoplankton grazers (Buskey \& Stockwell 1993, Montagna et al. 1993). The initiation of other major phytoplankton blooms have also been reported to develop as the result of the reduction or absence of zooplankton grazing (Granéli et al. 1989,

•E-mail: buskey@utmsi.zo.utexas.edu
Smayda \& Villareal 1989). An extensive fish kill and die-off of benthic organisms associated with the freeze released a pulse of nutrients to fuel the initial bloom (Buskey \& Stockwell 1993, DeYoe \& Suttle 1994). The bloom has persisted without interruption since its initiation. The most important unanswered question is: why has the brown tide persisted for so long?

Phytoplankton bloom formation requires that growth of the algal species exceed the sum of all loss processes, including losses to sinking, mixing, advection, disease, grazing and other sources of mortality. The Laguna Madre is a shallow system with little water exchange with the Gulf of Mexico, so losses of phytoplankton due to physical effects of sinking, mixing and advection are extremely small. Before the brown tide bloom began, phytoplankton populations were held at low biomass due to grazing by zooplankton, which balanced daily phytoplankton production (Buskey \& Stockwell 1993). Populations of the copepod Acartia tonsa appeared to be food limited, since enrichment studies showed increases in egg production rates with the addition of cultured phytoplankton to natural 
plankton assemblages (Buskey et al. unpubl.). After the brown tide began, microzooplankton community grazing rates decreased and copepod egg release rates measured in field incubations were reduced (Buskey \& Stockwell 1993). Field studies indicated that populations of microzooplankton and mesozooplankton declined after the brown tide began (Buskey \& Stockwell 1993). These changes in grazer populations during the brown tide were suspected to be due to the possibility that the brown tide was either a poor food for zooplankton or perhaps even toxic to some species. Disruption of zooplanktonic grazers on the brown tide may help explain the unusual persistence of this bloom.

The organism responsible for this bloom is a small (4 to $5 \mu \mathrm{m}$ diameter) phytoplankton species which has not yet been formally classified. The Texas 'brown tide' alga is devoid of obvious diagnostic features, but examination of ultrastructure by transmission electron microscopy and of photosynthetic pigments by high performance liquid chromatography reveal that it is similar in morphology and pigments to Aureococcus anophagefferens (Sieburth et al. 1988, Stockwell et al. 1993), which has been responsible for recurrent blooms in Narragansett Bay and Long Island Sound (NE USA) since 1985 (Cosper et al. 1987). Recent molecular data indicate that both species belong to a newly recognized class Pelagophyceae (Anderson et al. 1993) but the 2 species appear to differ enough from one another to warrant placing them in separate genera (DeYoe et al. 1995). Densities of this alga in nature have reached as high as $5 \times 10^{6} \mathrm{cells}^{-1}$, but typical densities are 0.2 to $2 \times 10^{6} \mathrm{ml}^{-1}$.

In this study we investigate the suitability of the Texas brown tide alga as a food to support the growth of several species of protozoa and a rotifer. We also measure egg production rates of Acartia tonsa in the laboratory and survival of $A$. tonsa nauplii fed the brown tide.

\section{MATERIALS AND METHODS}

The ciliates and heterotrophic dinoflagellates used in this study were collected from the University of Texas Marine Science Institute's pier in the channel between the Gulf of Mexico and Aransas Bay, in Port Aransas, Texas. Samples were collected with a $30 \mathrm{~cm}$ diameter, $20 \mu \mathrm{m}$ mesh net allowed to stream with the tide. These plankton samples were then screened through a $153 \mu \mathrm{m}$ mesh sieve to remove mesozooplankton. Aliquots of these samples were then incubated in 11 polycarbonate bottles and enriched with mixtures of cultured phytoplankton, including Dunaliella tertiolecta, Heterocapsa niei, Isochrysis galbana,
Pyrenomonas salina and the Texas brown tide alga. These enrichments were then placed on a bottle roller rotating at ca $2 \mathrm{rpm}$ and were incubated at $20^{\circ} \mathrm{C}$ at low light intensities for a period of several days. Enrichments were checked periodically for the growth of ciliates or heterotrophic dinoflagellates. When a species appeared to be growing well on the added phytoplankton species, individual cells were isolated under a stereo microscope and brought into culture. Ciliates brought into culture for this study include Fabrea salina, Strombidinopsis sp. and Euplotes sp. Heterotrophic dinoflagellates cultured for this study include Oxyrrhis marina and Noctiluca scintillans. Identification of ciliates and heterotrophic dinoflagellates are based on description in Lee et al. (1985). Cultures of the rotifer Brachionus plicatilus were acquired from the University of Texas Marine Science Institute's Fisheries and Mariculture Laboratory, and were originally isolated from local waters.

The large heterotrophic dinoflagellate Noctiluca scintillans and the copepod Acartia tonsa used for egg release and naupliar survival studies were collected using a $0.5 \mathrm{~m}$ diameter, $333 \mu \mathrm{m}$ mesh net, which was allowed to stream with a gentle outgoing tide. The contents of the cod end were immediately diluted into a plastic bucket containing whole seawater. The zooplankton sample was returned to the laboratory and $N$. scintillans or adult female A. tonsa were sorted from the sample with a wide bore pipette.

Protozoan stock cultures were maintained in 'ciliate media' (Gifford 1985) in $50 \mathrm{ml}$ tissue culture flasks held within a white PVC plastic cylinder on a bottle roller under the same conditions described for the enrichments. Cultures were fed every 3 to $4 \mathrm{~d}$, and transferred into new media at 1 wk intervals. Cultures were maintained on mixtures of phytoplankton (Fabrea salina, Euplotes sp. and Oxyrrhis marina: Isochrysis galbana and brown tide; Strombidinopsis sp.: Isochrysis galbana, Pyrenomonas salina and Heterocapsa niei; Noctiluca scintillans: Corethron criophilum, Ditylum brightwellii, Nitzschia thermalis, Thalassiosira sp.; Brachionus plicatilus: Isochrysis galbana).

Phytoplankton for these studies were grown in $f / 2$ culture media (Guillard \& Ryther 1962), except for the Texas brown tide alga which was grown on ESAW artificial seawater medium (Harrison et al. 1980 as modified by DeYoe \& Suttle 1994). Phytoplankton cultures were held in $250 \mathrm{ml}$ polycarbonate flasks at $20^{\circ} \mathrm{C}$ on a

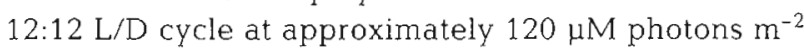
$\mathrm{s}^{-1}$ (photosynthetically available radiation measured with a Biospherical Instruments QSL-100 quantum scalar irradiance meter). Only rapidly growing phytoplankton cultures were used. Phytoplankton cells for elemental analysis were filtered onto precombusted $\mathrm{GF} / \mathrm{F}$ glass fiber filters, dried at $50^{\circ} \mathrm{C}$ and combusted in 
a Carlo Erba EA 1108 elemental analyzer. The volumes of phytoplankton cells were determined from measurements made at $200 \times$ or $400 \times$ magnification using a Wild M20 microscope and appropriate geometric formulas. Brown tide concentrations used in these studies

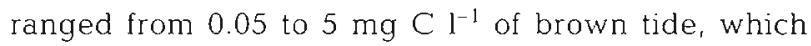
corresponds to approximately 0.05 to $5 \times 10^{5}$ cells $\mathrm{ml}^{-1}$, which is within the natural range of bloom concentrations.

Specific growth rates of protozoans (except Noctiluca scintillans) and rotifers on various concentrations of the brown tide alga and other phytoplankton species were measured by adding 2 or 3 organisms $\mathrm{ml}^{-1}$ to $150 \mathrm{ml}$ of ciliate media containing the desired species and concentration of phytoplankton. Triplicate $10 \mathrm{ml}$ samples were collected daily for $4 \mathrm{~d}$. Samples of Strombidinopsis sp., Fabrea salina, Euplotes sp. and Brachionus plicatilus were preserved with Lugol's iodine Samples were settled in Utermöhl chambers and enumerated using an inverted microscope (Olympus IMT$2)$. Specific growth rates $\left(\mu \mathrm{d}^{-1}\right)$ were calculated from the linear portion of $\ln$ (organisms $\mathrm{ml}^{-1}$ ) regressed against time (results were not used if growth was not exponential over a minimum of $3 \mathrm{~d}$ ). Growth rates of $N$. scintillans were measured by placing 20 cells in a $50 \mathrm{ml}$ plastic tissue culture flask with known phytoplankton concentrations. Flask were incubated on the bottle roller at $20^{\circ} \mathrm{C}$ for $3 \mathrm{~d}$ and the number of $\mathrm{N}$. scintillans at the end of the experiment was counted under a dissecting microscope. Specific growth rates were calculated as:

$$
\mu\left(\mathrm{d}^{-1}\right)=1 / t \ln \left(N_{t} / N_{0}\right)
$$

where $N_{0}$ and $N_{t}$ are the observed number of $N$. scintillans at the beginning and end of a time interval $t \mathrm{~d}$ long. Previous studies (Buskey 1995) have documented that $N$. scintillans maintains exponential growth at these food concentrations over a $3 \mathrm{~d}$ interval.

For egg release studies, 10 adult female Acartia tonsa were placed in each of ten $1200 \mathrm{ml}$ wide-mouth glass jars, with cultured phytoplankton of a single species at a concentration of $1.5 \mathrm{mg} \mathrm{C} \mathrm{l}^{-1}$ or 2 species at $1.5 \mathrm{mg} \mathrm{C} \mathrm{l}^{-1}$ each. This food concentration was chosen because preliminary studies indicated that this was just below the concentration yielding maximum egg release rates for copepods fed diatoms. The jars were then placed on a plankton wheel rotating at ca $2 \mathrm{rpm}$ within a walk-in growth chamber at $20^{\circ} \mathrm{C}$ on a $12: 12$ $\mathrm{L}: \mathrm{D}$ cycle. After $24 \mathrm{~h}$, the copepods were gently collected by pouring the sample through a $153 \mu \mathrm{m}$ mesh sieve and transferred into fresh seawater containing the same phytoplankton concentration. After another $24 \mathrm{~h}$ the contents of the jar was again screened through a $153 \mu \mathrm{m}$ mesh screen to remove the copepods, and then through a $20 \mu \mathrm{m}$ mesh screen to collect eggs and nauplii produced over the past $24 \mathrm{~h}$. The number of living $A$. tonsa adult females was counted and the number of eggs produced per adult female per day was calculated.

Newly hatched nauplii of Acartia tonsa were obtained by holding adult females within a $153 \mu \mathrm{m}$ mesh plastic sieve in a large culture dish containing filtered seawater overnight. In the morning the sieve and adult copepods were removed and the eggs produced that night were allowed to hatch. Survival of $A$. tonsa nauplii on various phytoplankton foods was determined by placing a single N1 nauplius in each of 24 wells of a tissue culture plate containing $3 \mathrm{ml}$ of phytoplankton culture at a concentration of $5 \mathrm{mg}$ carbon $\mathrm{l}^{-1}$. Each well was checked daily to monitor the survival of the copepod over a $5 \mathrm{~d}$ period. A second naupliar survival experiment was run by placing 50 newly hatched nauplii in a $50 \mathrm{ml}$ tissue culture flask with a known concentration of phytoplankton (2.3.5 or $5 \mathrm{mg} \mathrm{C} \mathrm{I}^{-1}$ ). These flasks were incubated on bottle rollers as described for protozoan cultures above, and the number of nauplii surviving after $5 \mathrm{~d}$ was determined.

\section{RESULTS}

Specific growth rates of the ciliate Strombidinopsis sp. fed Pyrenomonas salina increased with increases in food concentration until a maximum growth rate of $0.96 \mathrm{~d}^{-1}$ was achieved at a food concentration of $1 \mathrm{mg}$ $\mathrm{C}^{-1}$ (Fig. 1). When this same species was fed the Texas brown tide alga, all specific growth rates were negative, indicating mortality rather than growth on this food source. Since specific growth (death) rates became more negative as food concentrations of brown tide increased, it appears that the brown tide is toxic to this species.

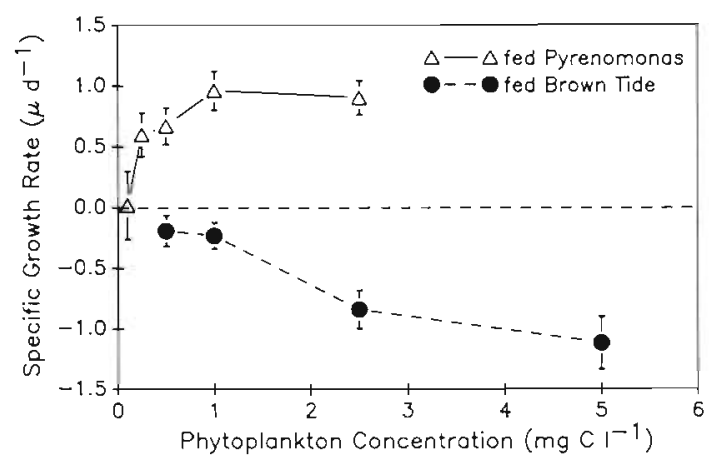

Fig. 1. Specific growth rate $\left(\mathrm{d}^{-1}\right)$ of the ciliate Strombidinopsis $\mathrm{sp}$. on various concentrations of the Texas brown tide alga and on Pyrenomonas salina. Error bars represent the standard error of the slope of line for the natural logarithm of the number of cells regressed against time, used to determine specific growth rates 


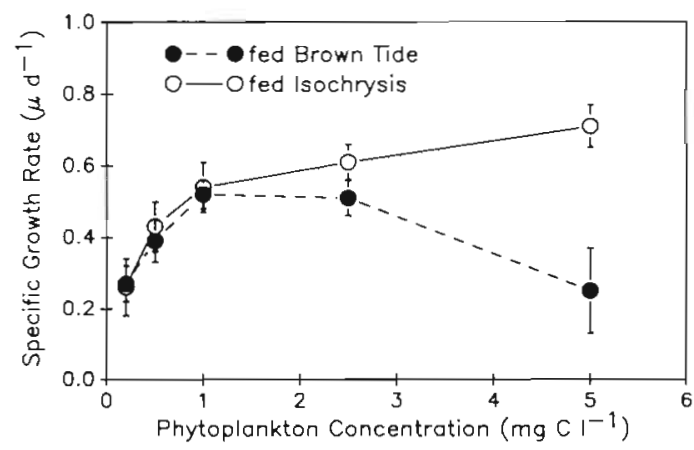

Fig. 2. Specific growth rate $\left(\mathrm{d}^{-1}\right)$ of the ciliate Fabrea salina on various concentrations of the Texas brown tide alga and on Isochrysis galbana. Error bars as in Fig. 1

In contrast, the ciliates Fabrea salina and Euplotes sp. grew well on the brown tide. Maximum specific growth rate for $F$. salina of $0.52 \mathrm{~d}^{-1}$ was achieved at $1 \mathrm{mg} \mathrm{C} \mathrm{^{-1 }}$ of brown tide. However, the numerical response of $F$. salina to various concentrations of the brown tide alga shows a decreasing growth rate at food concentrations above $1 \mathrm{mg} \mathrm{Cl}^{-1}$, falling to $0.25 \mathrm{~d}^{-1}$ at $5 \mathrm{mg} \mathrm{Cl}^{-1}$ (Fig. 2). In contrast, F salina fed Isochrysis galbana showed a more typical numerical response curve, with growth rate remaining high at higher food concentrations (maximum specific growth rate of 0.71 $\mathrm{d}^{-1}$ at $5 \mathrm{mg} \mathrm{C} \mathrm{I}^{-1}$ ) The ciliate Euplotes $\mathrm{sp}$. showed a similar numerical response when fed the brown tide alga. Maximum specific growth rates of $0.5 \mathrm{~d}^{-1}$ were observed at a brown tide concentration of $1 \mathrm{mg} \mathrm{Cl}^{-1}$, but specific growth rates fell to 0.29 at $5 \mathrm{mg} \mathrm{C} \mathrm{l}^{-1}$ (Fig. 3). Growth of Euplotes sp. was higher when fed $I$. galbana at 2.5 or $5 \mathrm{mg} \mathrm{C}^{-1}$ than when fed similar concentrations of the brown tide.

The Texas brown tide alga did not support the growth of the heterotrophic dinoflagellate Noctiluca scintillans. However, there is no evidence that the brown tide alga is highly toxic to $N$. scintillans, since

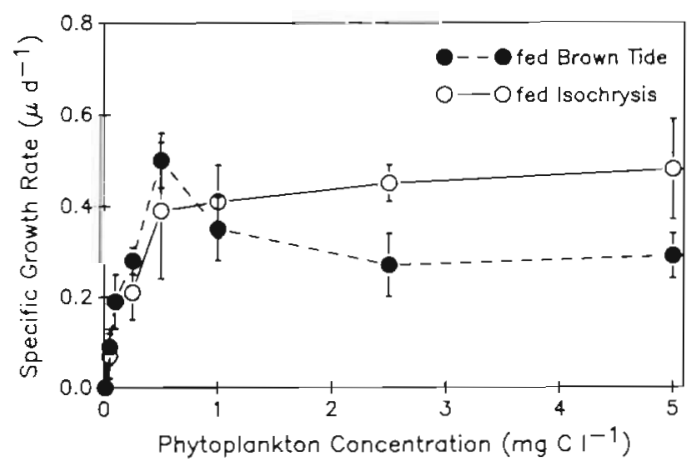

Fig. 3. Specific growth rates $\left(\mathrm{d}^{-1}\right)$ of the ciliate Euplotes sp. on various concentrations of the Texas brown tide alga and on Isochrysis galbana. Error bars as in Fig. 1

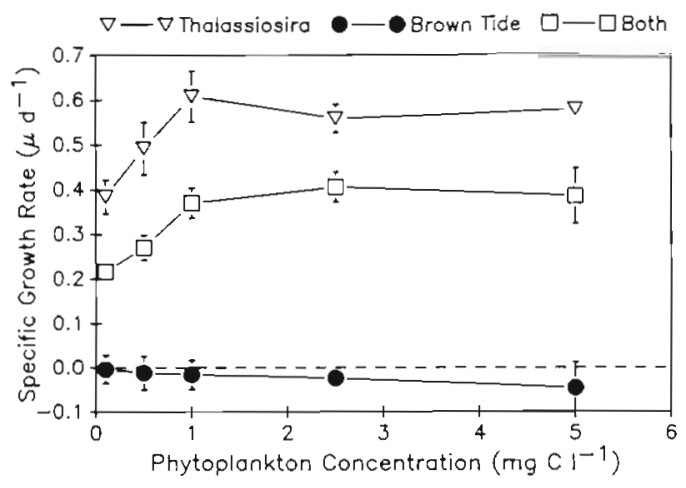

Fig. 4. Specific growth rates $\left(\mathrm{d}^{-1}\right)$ of the heterotrophic dinoflagellate Noctiluca scintillans on various concentrations of the Texas brown tide alga, Thalassiosira sp. or equal concentrations of both species (twice the total food concentration). Each point is the mean $( \pm S D$ ) of 3 growth experiments

growth (death) rate was only $-0.04 \mathrm{~d}^{-1}$ at $5 \mathrm{mg} \mathrm{Cl}^{-1}$ of brown tide. Specific growth rates of $N$. scintillans on

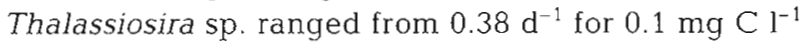
to $0.6 \mathrm{~d}^{-1}$ (Fig. 4). When a mixture of Thalassiosira sp. and the brown tide alga was offered as food, the specific growth rate ranged from 0.22 to $0.38 \mathrm{~d}^{-1}$. Even though total food concentration was twice as high when equal amounts of brown tide and Thalassiosira sp. were offered as food, growth rates were always lower than when $N$. scintillans were offered Thalassiosira sp. alone.

The small heterotrophic dinoflagellate Oxyrrhis marina did not grow on brown tide at concentrations below $0.1 \mathrm{mg} \mathrm{Cl}^{-1}$, but grew well on higher concentrations of this species (Fig. 5). Maximum specific growth rates of $0.55 \mathrm{~d}^{-1}$ were observed at a concentration of $5 \mathrm{mg} \mathrm{C} \mathrm{I}^{-1}$. However, growth rates of $O$. marina were higher when fed equivalent concentrations of $I$. galbana than when fed the brown tide alga at concentrations below $5 \mathrm{mg} \mathrm{Cl}^{-1}$ (Fig. 5), with maximum growth

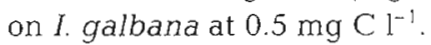

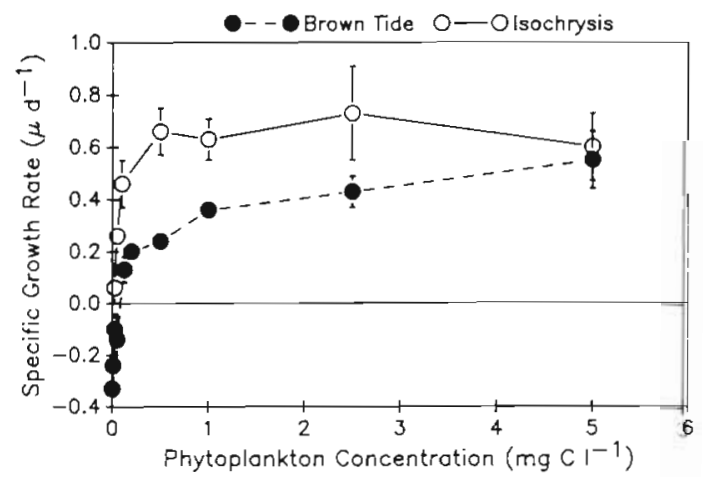

Fig. 5. Specific growth rates $\left(\mathrm{d}^{-1}\right)$ of the heterotrophic dinoflagellate Oxyrrhis marina on the Texas brown tide alga and on Isochrysis galbana. Error bars as in Fig. 1 


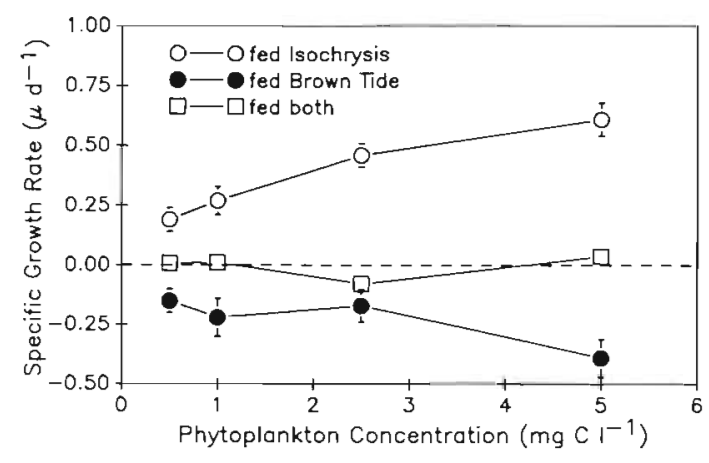

Fig. 6. Specific growth rates $\left(\mathrm{d}^{-1}\right)$ of the rotifer Brachionus plicatilus on the Texas brown tide alga, Isochrysis galbana and equal concentrations of each (twice the total food concentration). Error bars as in Fig. 1

The Texas brown tide alga did not support the growth of the rotifer Brachionus plicatilus at any food concentration. Specific growth (death) rates were similar to those for rotifers that were starved over the same $3 \mathrm{~d}$ period $\left(\mathrm{ca}-0.15 \mathrm{~d}^{-1}\right)$. At a brown tide concentration of $5 \mathrm{mg} \mathrm{Cl}^{-1}$, specific growth (death) rate decreased to -0.39 . When the rotifers were fed Isochrysis galbana, specific growth rates ranged from 0.19 to $0.61 \mathrm{~d}^{-1}$ (Fig. 6). However, when B. plicatilus was fed an equal amount of both $I$. galbana and the Texas brown tide alga (yielding twice the total phytoplankton concentration), B. plicatilus showed little or no growth.

When groups of 36 Acartia tonsa nauplii were raised in $3 \mathrm{ml}$ cell wells in tissue culture plates, the group held without any food exhibited daily mortality and were all dead by the end of a $5 d$ period. For a similar group of nauplii held in $3 \mathrm{ml}$ of seawater containing brown tide at a concentration of $5 \mathrm{mg} \mathrm{C} \mathrm{^{-1 }}$, there was extensive mortality on Day 2 , and all nauplii were dead by Day 3. For groups of nauplii raised on $5 \mathrm{mg} \mathrm{Cl}^{-1}$ of Isochrysis galbana, Pyrenomonas salina or a combination of the 2 foods, over $85 \%$ of the nauplii were still

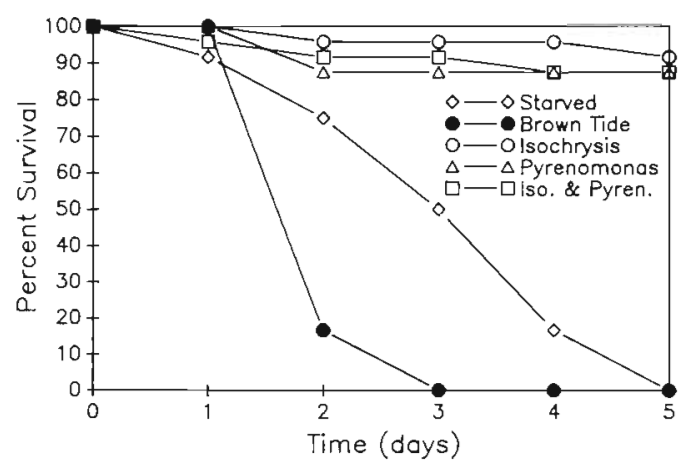

Fig. 7. Survival of groups of 24 nauplii of the copepod Acartia tonsa fed $5 \mathrm{mg} \mathrm{C}^{-1}$ of the Texas brown tide alga, Isochrysis galbana, Pyrenomonas salina, a combination of 1 . galbana and P. salina or starved over a $5 \mathrm{~d}$ period

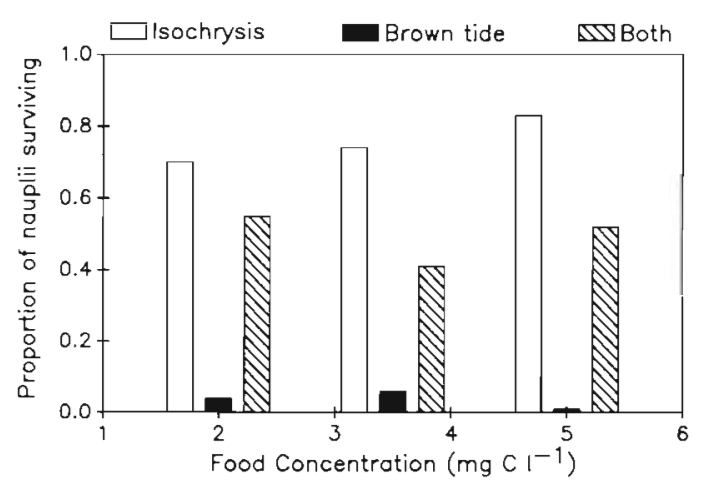

Fig. 8. Survival of groups of 50 nauplii of the copepod Acartia tonsa fed Isochrysis galbana, the Texas brown tide alga or a combination of both (twice the total food concentration) at food concentrations of $2,3.5$ and $5 \mathrm{mg} \mathrm{Cl}^{-1}$ over a $5 \mathrm{~d}$ period.

Each bar is the mean value of 2 replicate experiments

alive at the end of the $5 \mathrm{~d}$ period (Fig. 7). Since the brown tide appeared to settle to the bottom of the cell wells over the course of the experiment, subsequent experiments were done with groups of 50 nauplii in $50 \mathrm{ml}$ tissue culture flasks rotated at $2 \mathrm{rpm}$ to keep the algae in suspension. Replicate experiments were run at 2, 3.5 and $5 \mathrm{mg} \mathrm{C}^{-1}$. Survival of $A$. tonsa nauplii ranged from 1 to $6 \%$ on the brown tide alone, from 70 to $83 \%$ on I. galbana alone and from 41 to $55 \%$ on a combination of equal amounts of each food (twice the food concentration) (Fig. 8).

Egg release rates for adult female Acartia tonsa fed the Texas brown tide alga at a food concentration of $1.5 \mathrm{mg} \mathrm{C}^{-1}$ was $3.4 \pm 2.3$ (mean $\pm 1 \mathrm{SD}, \mathrm{n}=6$ ) eggs female ${ }^{-1} \mathrm{~d}^{-1}$, which was not significantly different from the egg release rates of $1.7 \pm 0.7$ for $A$. tonsa that had been starved over the same $48 \mathrm{~h}$ period ( $t$-test, $\alpha=$ 0.05) (Fig. 9). A. tonsa females fed similarly sized small phytoplankton species showed intermediate egg release rates of $9.3 \pm 2.6$ eggs female ${ }^{-1} \mathrm{~d}^{-1}$ when fed

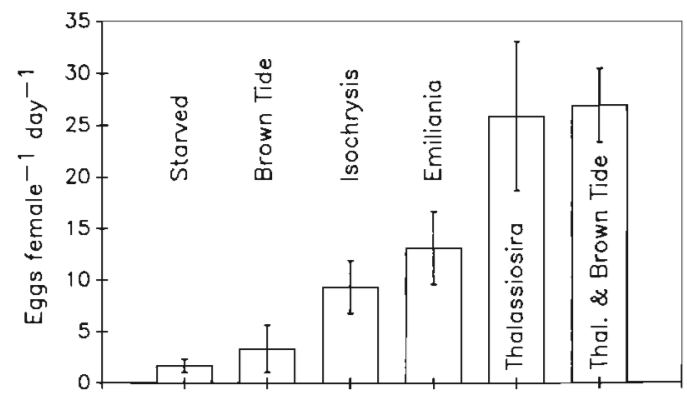

Fig. 9. Mean egg release rates (eggs female $\mathrm{e}^{-1} \mathrm{~d}^{-1}$ ) of adult

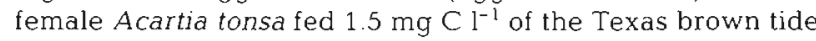
alga, Isochrysis galbana, Emiliania huxleyi, Thalassiosira sp., a combination of Thalassiosira sp and brown tide, or starved. Each bar represents the mean $( \pm S D)$ of 8 replicate experiments 
$1.5 \mathrm{mg} \mathrm{C}^{-1}$ of Isochrysis galbana (5 $4 \mathrm{~m}$ diameter) and $13.1 \pm 3.5$ eggs female ${ }^{-1} \mathrm{~d}^{-1}$ when fed $1.5 \mathrm{mg} \mathrm{Cl}^{-1}$ of Emiliania huxleyi (4 $\mathrm{mm}$ diameter). Highest egg release rates of $25.9 \pm 7.2$ eggs female ${ }^{-1} \mathrm{~d}^{-1}$ were mea-

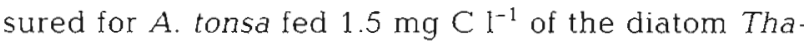
lassiosira $\mathrm{sp}$. When $A$. tonsa females were offered a combination of $1.5 \mathrm{mg} \mathrm{C}^{-1}$ each of Thalassiosira sp.

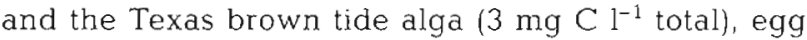
release rates were $26.9 \pm 3.6$ eggs female ${ }^{-1} \mathrm{~d}^{-1}$, which is not significantly different from the release rate when the copepods were fed Thalassiosira sp. alone ( $t$-test, $\alpha$ $=0.05$ ).

\section{DISCUSSION}

The Texas brown tide alga appears to be a poor food for a variety of zooplankton species. It supports no growth of the ciliate Strombidinopsis sp., the heterotrophic dinoflagellate Noctiluca scintillans or the rotifer Brachionus plicatilus. It is not unusual to find zooplankton that can not be cultured on a particular species of phytoplankton; some can only capture particles in a relatively narrow size range (Fenchel 1980). However, $N$. scintillans can be grown on a wide variety of phytoplankton species, including species of similar size (Buskey 1995), and B. plicatilus is very easy to culture and is widely used as a food for larval fish. Based on the results of this study, there is evidence that the brown tide may be directly toxic to some species of zooplankton, at cell concentrations similar to those found in nature. For the ciliate Strombidinopsis sp. (Fig. 1) and for the rotifer B. plicatilus (Fig. 6), mortality rates increase with increasing brown tide concentration. For one experiment with Acartia tonsa nauplii, mortality was faster in the presence of the brown tide than when no food was offered (Fig. 7). Additional evidence for toxicity of the brown tide to some species of zooplankton comes from the decrease in survival of $A$. tonsa nauplii when both a suitable food (Isochrysis galbana) and the brown tide are offered together (Fig. 8). In addition, when both $I$. galbana and the brown tide are offered together, growth of the heterotrophic dinoflagellate $N$. scintillans and the rotifer $B$. plicatilus are inhibited (Figs. $4 \& 6$ ). In contrast, there is little evidence that the related species Aureococcus anophagefferens is toxic to microzooplankton. No evidence was found for changes in protozoan grazing rate or for suppression of growth in protozoans fed $A$. anophagefferens, nor was there any evidence that $A$. anophagefferens caused a reduction in protozoan populations in nature (Caron et al. 1989)

The brown tide alga appears to be a poor food for Acartia tonsa, the dominant mesozooplankter in the Laguna Madre. Egg release rates of adult females fed the brown tide were not significantly different from those held without food over the same time interval. This may have been due in part to the small size of the brown tide cells ( 4 to $5 \mu \mathrm{m}$ diameter), which is outside the optimum size range for particle capture by $A$. tonsa (Berggreen et al. 1988). However, A. tonsa females produced an intermediate number of eggs on 2 similarly small-sized algal species, indicating that size alone was not the problem. There was no evidence of brown tide toxicity to adult female $A$. tonsa at $1.5 \mathrm{mg} \mathrm{C}$ $\mathrm{l}^{-1}$, since there was no direct mortality to adults and egg release was not lowered with the combination of Thalassiosira and brown tide. Lower egg release rates are reported for $A$. tonsa fed picoalgae during an Aureococcus anophagefferens bloom in Narragansett Bay (Durbin \& Durbin 1989). In addition to lowering the egg release rates of adult females, the presence of the brown tide resulted in lower survival of $A$. tonsa nauplii, suggesting toxic effects. The Texas brown tide alga has also been shown to be toxic to yolk-sac and first feeding red drum and spotted sea trout larvae (G. J. Holt pers. comm.) but it does not appear to have adverse affects on adult fish populations.

Field evidence also supports the concept that the Texas brown tide alga is a poor food for zooplankton and disrupts trophic transfer in the planktonic food web. Mesozooplankton abundance (mainly Acartia tonsa) was lower in the Laguna Madre after the brown tide began than in the preceding year, and adult female $A$. tonsa were smaller and produced fewer eggs in field incubations than before the brown tide began (Buskey \& Stockwell 1993). Microzooplankton abundances were also lower after the brown tide began, and microzooplankton community grazing rates of phytoplankton standing stock were reduced from ca $95 \%$ to less than $5 \%$ during the brown tide (Buskey \& Stockwell 1993). It is still difficult to understand why species of microzooplankton capable of growing on the brown tide have not flourished and helped bring the brown tide under control. It is possible that $A$. tonsa may be exerting additional predation pressure on microzooplankton populations during the brown tide, due to the reduction of other species of phytoplankton in their preferred size range. It is well documented that A. tonsa also feed on microzooplankton (reviewed in Pierce \& Turner 1992), so it is possible that they are holding microzooplankton populations below a level where they can exert sufficient grazing pressure to help control the brown tide.

The related brown tide species Aureococcus anophagefferens has been demonstrated to inhibit feeding and cause mass mortality of the mussel Mytilus edulis (Tracey 1988). Bricelj \& Kuenster (1989) concluded that this mortality was due to toxicity and not to small size or nutritional inadequacy of this phytoplankton species. Laboratory studies also indicate that $A$. anophag- 
efferens reduces growth and causes high mortality of bay scallop larvae (Gallager et al. 1989). A. anophagefferens was shown to inhibit the ciliary activity of isolated gills of some bivalve species such as Mercenaria mercenaria and Mytilus edulis but not others that were affected by brown tide in nature such as Argopecten irradians (Gainey \& Shumway 1991). In contrast, the Texas brown tide alga is readily consumed by the dwarf surfclam Mulinia lateralis without adverse affects (Montagna et al. 1993) and there is no evidence that the Texas brown tide alga is toxic to adults of other species of invertebrates.

It seems likely that the Texas brown tide alga may produce a chemical that inhibits grazing or growth of microzooplankton, and/or may act as an allelopathic agent to reduce competition from other phytoplankton species. For example, both Aureococcus anophagefferens and the Texas brown tide contain high concentrations of dimethylsulfoniopropionate (DMSP), which is a precursor to dimethylsulfide (DMS) and acrylic acid (Keller et al. 1989, Stockwell et al. 1993). The role of DMSP in grazer inhibition is unclear, however. For example, Phaeocystis pouchetii, which also produces a large amount of DMSP (Keller et al. 1989), appears to be consumed by a wide variety of zooplankton (Admiraal \& Venekamp 1986, Huntley et al. 1987), whereas Chrysochromulina polylepis, which also produces DMSP, reduces growth and feeding rates of the tintinnid Favella ehrenbergii (Carlsson et al. 1990). The polysaccharide-like layer on the surface of $A$. anophagefferens contains a bioactive compound responsible for the reduction in ciliary beat frequency in bivalve gills (Gainey \& Shumway 1991) but no similar compounds have yet been identified in the Texas brown tide alga.

Many species of harmful and nuisance algae are toxic to a variety of marine organisms. Most of the toxins associated with harmful algal blooms were first noticed because of the extensive fish kills they caused or for the human health risk associated with consumption of contaminated seafoods. It is difficult to understand why algal species would evolve toxins that were specifically aimed at humans or fish species that do not directiy consume these algal species. It is possible that in some cases these toxins might be substances that have evolved for some other physiological function in the cell, which coincidentally happen to be toxic to human or marine life. In the cases of Aureococcus anophagefferens and the Texas brown tide alga, it appears as if toxic substances may be targeted at benthic and planktonic grazers that feed on these species of phytoplankton, and although there are no direct threats to human health from these species, they may have a profound effect on the structure and function of the ecosystems in which they reside.
Acknowledgements. This work was supported by the Texas Higher Education Coordinating Board, Advanced Technology Program under Grant No. TATP-426. This is University of Texas Marine Science Institute contribution number 948 .

\section{LITERATURE CITED}

Admiraal W, Venekamp LAH (1986) Significance of tintinnid grazing during blooms of Phaeocystis pouchetii (Haptophyceae) in Dutch coastal waters. Neth J Sea Res 20:61-66

Andersen RA, Saunders GW, Paskind MP, Sexton JP (1993) Ultrastructure and $18 \mathrm{~s} r$ RNA gene sequence for Pelagomonas calceolata gen. et sp. nov. and the description of a new algal class, the Pelagophyceae classis nov J Phycol 29:701-715

Berggreen U, Hansen B, Kiørboe $\Upsilon$ (1988) Food size spectra, ingestion and growth of the copepod Acartia tonsa during development: implications for determination of copepod production. Mar Biol 99:341-352

Bricelj VM, Kuenstner SH (1989) Effects of the 'brown tide' on the feeding, physiology and growth of bay scallops and mussels. In: Cosper EM, Bricelj VM, Carpenter EJ (eds) Novel phytoplankton blooms. Coastal and estuarine studies 35. Springer-Verlag, Berlin, p 491-509

Buskey EJ (1995) Growth and bioluminescence of Noctiluca scintillans on varying algal diets. J Plankton Res 17:29-40

Buskey EJ, Stockwell DA (1993) Effects of a persistent 'brown tide' on zooplankton populations in the Laguna Madre of South Texas. In: Smayda TJ, Shimizu Y (eds) Toxic phytoplankton blooms in the sea. Proc 5th Int Conf Toxic Marine Phytoplankton. Elsevier, Amsterdam, p 659-666

Carlsson P, Granéli E, Olsson P (1990) Grazer elimination through poisoning: one of the mechanisms behind Chrysochromulina polylepis blooms? In: Granéli E, Sundstrom B. Edler L, Anderson DM (eds) Toxic marine phytoplankton. Elsevier, New York, p 116-122

Caron DA, Lim E, Kunze H, Cosper EM, Anderson DM (1989) Trophic interactions between nano- and microzooplankton and the 'brown tide' In: Cosper EM, Bricelj VM, Carpenter EJ (eds) Novel phytoplankton blooms. Coastal and estuarine studies 35. Springer-Verlag, Berlin, p 265-294

Cosper EM, Dennison WC, Carpenter EJ, Bricelj VM. Mitchell JG, Kuenstner SH, Colflesh D, Dewey M (1987) Recurrent and persistent brown tide blooms perturb a coastal marine ecosystem. Estuaries 10:284-290

DeYoe HR, Suttle CA (1994) The inability of the Texas 'brown tide' alga to use nitrate and the role of nitrogen in the initiation of a persistent bloom of this organism. J Phycol 30: $800-806$

DeYoe HR, Chan AM, Suttle CA (1995) Phylogeny of Aureococcus anophagefferens and a morphologically similar bloom forming algae from Texas as determined by $18 \mathrm{~s}$ rRNA sequence analysis. J Phycol 31:413-418

Durbin AG, Durbin EG (1989) Effect of the 'brown tide' on feeding, size and egg laying rate of adult female Acartia tonsa. In: Cosper EM, Bricelj VM, Carpenter EJ (eds) Novel phytoplankton blooms. Coastal and estuarine studies 35. Springer-Verlag, Berlin, p 625-646

Fenchel $T$ (1980) Suspension feeding in ciliated protozoa: functional response and particle size selection. Microb Ecol 6:1-11

Gainey LF Jr, Shumway SE (1991) The physiological effect of Aureococcus anophagefferens ('brown tide') on the lateral cilia of bivalve mollusks. Biol Bull 181:298-306

Gallager SM, Stoecker DK, Bricelj VM (1989) Effects of the brown tide alga on growth, feeding physiology and loco- 
motory behavior of scallop larvae (Argopecten irradians). In: Cosper EM, Bricelj VM, Carpenter EJ (eds) Novel phytoplankton blooms. Coastal and estuarine studies 35. Springer-Verlag, Berlin, p 511-541

Gifford DJ (1985) Laboratory culture of marine planktonic oligotrichs (Ciliophora, Oilgotricha). Mar Ecol Prog Ser 23:257-267

Granéli $E_{1}$ Olsson $P$, Carlsson $P$, Sundstrom $B$, Lindahl $O$ (1989) From anoxia to fish poisoning: the last ten years of phytoplankton blooms in Swedish marine waters. In: Cosper EM, Bricelj VM, Carpenter EJ (eds) Novel phytoplankton blooms. Coastal and estuarine studies 35 . Springer-Verlag, Berlin, p 407-428

Guillard RRL, Ryther RH (1962) Studies of marine planktonic diatoms. I. Cyclotella nana Hustedt and Detonula confervacea Cleve Gran. Can J Microbiol 8:229-239

Harrison PJ, Waters RE, Taylor JFR (1980) A broad spectrum artificial seawater medium for coastal and open ocean phytoplankton. J Phycol 16:28-35

Huntley M, Tande K, Eilertsen HC (1987) On the trophic fate of Phaeocystis pouchetii Hariot. II. Grazing rates of Calanus hyperboreus. J exp mar Biol Ecol 110:197-212

Keller MD, Bellows WK, Guillard RRL (1989) Dimethylsulfide production and marine phytoplankton: an additional impact of unusual blooms. In: Cosper EM, Bricelj VM, Carpenter EJ (eds) Novel phytoplankton blooms. Coastal and estuarine studies 35. Springer-Verlag, Berlin, p $511-541$

This article was submitted to the editor
Lee JJ, Hutner SH, Bovee EC (1985) An illustrated guide to the protozod. Society of Protozoologists, Lawrence, KS

Montagna PA, Stockwell DA, Kalke RD (1993) Dwarf surfclam Mulinia lateralis (Say, 1822) populations and feeding during the Texas brown tide event. $J$ Shellfish Res 12 : $433-442$

Pierce RW, Turner JT (1992) Ecology of planktonic ciliates in marine food webs. Rev aquat Sci 67:1710-1714

Sieburth JM, Johnson PW, Hargraves PE (1988) Ultrastructure and ecology of Aureococcus anophagefferens gen. et sp. nov. (Chrysophyceae): the dominant picoplankter during a bloom in Narragansett Bay, Rhode Island, summer 1985. J Phycol 24:416-425

Smayda TJ, Villareal, TA (1989) The 1985 'brown tide' and the open phytoplankton niche in Narragansett Bay during summer. In: Cosper EM, Bricelj VM, Carpenter EJ (eds) Novel phytoplankton blooms. Coastal and estuarine studies 35. Springer-Verlag, Berlin, p 159-188

Stockwell DA, Buskey EJ, Whitledge TE (1993) Studies on conditions conducive to the development and maintenance of a persistent 'brown tide' in Laguna Madre, Texas. In: Smayda TJ, Shimizu Y (eds) Toxic phytoplankton blooms in the sea. Proc. 5th Int. Conf. Toxic Marine Phytoplankton. Elsevier, Amsterdam, p 693-698

Tracey GA (1988) Feeding reduction, reproductive failure, and mortality in Mytilus edulis during the 1985 'brown tide' in Narragansett Bay, Rhode Island. Mar Ecol Prog Ser $50.73-81$

Manuscript first received: February 23, 1995 Revised version accepted: May 2, 1995 